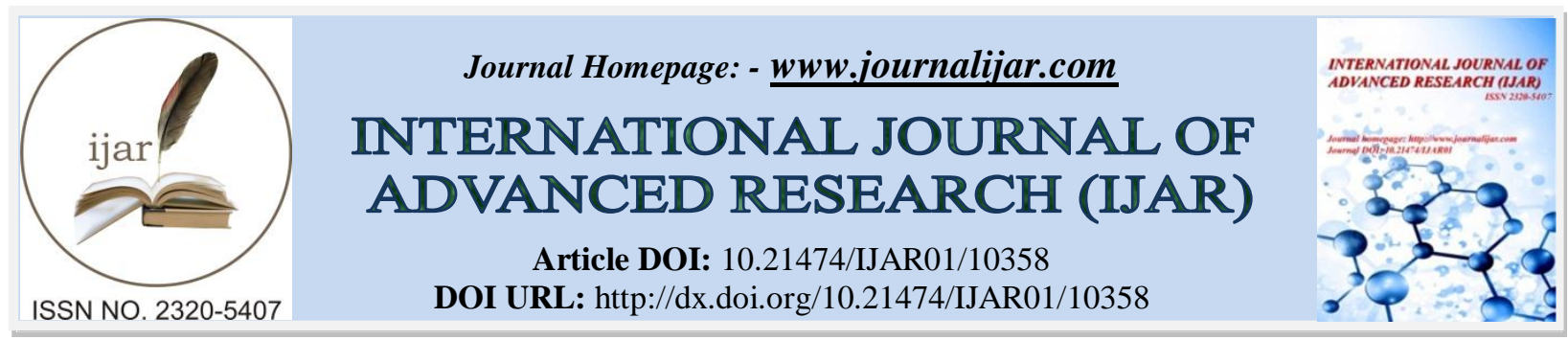

RESEARCH ARTICLE

\title{
ENTREPRENEUR PERSONALITY TRAITS AND BEHAVIORS MEASUREMENT USING SPATIAL MEASUREMENT
}

\section{Noorain Mohd. Nawawi ${ }^{1}$ and Uznir Ujang ${ }^{2}$}

1. Research Scholar, Department of Geoinformation, Faculty of Built Environment and Surveying, Universiti Teknologi Malaysia (UTM), Johor, Malaysia.

2. Lecturer, Department of Geoinformation Faculty of Built Environment and Surveying, Universiti Teknologi Malaysia (UTM), Johor, Malaysia.

\section{Manuscript Info}

.........................

Manuscript History

Received: 30 November 2019

Final Accepted: 31 December 2019

Published: January 2020

Key words:-

Entrepreneur, Personality Traits And Behaviors, Spatial Perspective, Spatial Measurement, GIS

\section{Abstract}

The government and the private sector encouraged entrepreneurship by offering various types of loans that provide employment opportunities as an effort to reduce poverty. Evidence has shown that personality traits and behaviors are vital roles in influencing entrepreneurship. Different evaluations should be done, including tests of personality traits and behavior. Agencies typically use a common method in evaluating entrepreneurs, such as self-reporting, interviews, and questionnaires. Nevertheless, psychologists and social researchers strongly question the shortcomings of these evaluation methods. The drawbacks of these methods include bias and entrepreneurs can fake their answers (Social Desirability Response). These circumstances reduce the chance of an honest and prospective entrepreneur to get loans when judged against an entrepreneur who knows how to exploit their answers to impress the evaluators. In order to avoid false answers and biases, numerous attempts have been carried out to assess entrepreneur personality traits and behavior objectively. Geographical space influence the behavior of entrepreneurs (activities) and the entrepreneur's activities can also influence changes in the geographical space. Therefore, it is advisable to include spatial components in personality and behavior evaluation. This article suggests a different approach in evaluating potential entrepreneurs that assesses personality traits and behaviors from a spatial perspective. A total of 100 questionnaires were distributed to micro-entrepreneurs and agencies which provide loans for micro-entrepreneurs. SmartPLS3 software is used for data processing and analysis following the collection of data. It was concluded from the results of this study, it is possible to evaluate personality and behaviors from a spatial perspective.

Copy Right, IJAR, 2020,. All rights reserved.

\section{Introduction:-}

Nowadays, entrepreneurship is a way to encourage job seekers by creating jobs for others (Nwachukwu, 2012). Poverty is a chronic problem for most developing and underdeveloped countries, and entrepreneurship is one of several countries' sources of direct and indirect employment. Many parties, such as government agencies, private 
sectors, and researchers have taken an interest in entrepreneurship. Therefore, offering funding and assistance in order to start or grow businesses for aspiring or established entrepreneurs is very useful. In order to be granted a loan, applicants must undergo multiple tests before the application is approved. These tests are necessary in order to determine the eligibility and willingness of the applicants to repay the loans received. In addition, an evaluation of the applicant's personality is also included as one of the facets to be evaluated. Earlier researchers have already emphasized various types of entrepreneurial behaviors, which can lead to the success of entrepreneurs (Ahmad \& Kadir, 2013; Hachana, Berraies, \& Ftiti, 2018). Personality evaluation is not an easy task because it requires a nondefined approach based on different individual experiences and perspectives (de-Juan-Ripoll et al., 2018; Youyou, Kosinski, \& Stillwell, 2015). Personality evaluation usually includes self-reports, interviews, and a questionnaire. While this approach is commonly used, psychologists and social theorists condemn the deficiencies of the evaluation method (Baumeister, Vohs, \& Funder, 2007; Hammersley, 2013; Uher, 2015).

The self-report approach is one of the best-known approaches for evaluating entrepreneurs used by various agencies. Respondents can be asked about their feelings and experiences as an indication of their thoughts and viewpoint, which may not be easily expressed by them. Information about thoughts or feelings can only be obtained if respondents are willing to share their views honestly. Inaccuracies and contradictions might be encountered in using the self-report method. Such flaws are referred to as the Social Desirability Response (SDR), whereby respondents tend to make a good impression or fake an answer to improve their image. Another typical procedure to access potential entrepreneurs is based on the offline or online personality questionnaires. In general, several questions were answered or chosen from 3 to 7 or more answers. This questionnaire generally uses Likert to assess opinions on a micro and macro scale and become one of the most reliable methods for assessing beliefs and behaviors (Podsakoff, MacKenzie, Lee, \& Podsakoff, 2003). Another method used is an interview, which can be done in a formal and informal setting (Dipboye, 1994). A formal interview may reduce the possibility of bias (Hogan, Barrett, \& Hogan, 2007). Nonetheless, in a formal interview process, biases, mistakes, and confusion can sometimes occur. For instance, applicants with features that interviewers anticipate and prefer can benefit those candidates, which will lead to a high evaluation. In comparison to an informal interview, the setting can be more fun, relaxed, and comfortable (Phellas, Bloch, \& Seale, 2011). Nevertheless, this subjective approach will reduce the precision of the evaluation (Conway, Jako, \& Goodman, 1995).

All the above methods are a common and popular approach, but the traits and behaviors of entrepreneurship today have been changed by technology and space. In certain locations and times, entrepreneurship takes place and always takes space. Therefore the previously mentioned methods appear incomplete and unfinished as they rely solely on personality and behaviors without taking into account the spatial and technological dimension. The use of personalities and behavioral evaluation by information and communication technology, such as geographical information systems (GIS), is still limited (Alessandretti, Lehmann, \& Baronchelli, 2018; Kwan, 2000). GIS systems are commonly known as geospatial information collection, tracking, analysis, manipulation, and visualization tool. In GIS, a spatial measurement that includes numerical values is used in order to explain and describe geographical data characteristics or better known as spatial data (Longley, Goodchild, J., \& Rhind, 2001). This data is stored, processed, transferred and shown using computer hardware and computer-based technology to answer questions about spatial element, such as location shape size and the relationship between objects (Esri, 2003). While personality traits and behaviors are somewhat difficult to measure, spatial measurements may serve as an instrument to quantify personality traits and behaviors objectively (Kwan, 2000). This is because personality traits and behaviors are always defined as something subjective, impossible to quantify, and also intangible. With the use of GIS, the individual traits and behaviors of entrepreneurs can be calculated, analyzed, and modeled to gain more significant information

\section{Research Approach:-}

This research was conducted by using the analytical approach where the research question is defined before deconstructed into smaller components that can be efficiently completed in each stage. In order to study entrepreneurship, several places in Johor, which partakes in entrepreneurship activities, were visited during preliminary research. In this visit, several entrepreneurs were interview to gain information about personality traits that can influence in their business successfulness. Several interviews were carried out for agencies staff which provide loan to micro entrepreneurs in order to gain information from staff perspective. This research continues with the "desk research" approach to identify and cross check entrepreneurs' typical behaviors and personality traits. In order to measure entrepreneurs' personality traits and behaviors, any spatial elements embedded in an entrepreneur's behaviors were identified. persistence, determination, and opportunity oriented were chosen as the personality traits 
to be evaluated in this research. These personality traits were chosen as based on the finding from interview and literature review they were evident. The final phase of this research is the validation phase, where the identified spatial elements and behaviors of the personalities selected were validated.

The quantitative methodology used in this research consists of a questionnaire which assessed the entrepreneur's opinions regarding their behaviors and personality traits for spatial measurement purpose. The questionnaire consists of five sections. Section A focuses on the respondent's background, and Section B focuses on identifying and recognizing the most appropriate entrepreneurial behaviors and personalities. Section $\mathrm{C}$ is for the evaluation of the entrepreneur's behaviors and personality traits, while in Section D, the use of spatial measurements is to assess the actions and personality of an entrepreneur objectively, and finally, Section E questions the sharing of data between agencies. This questionnaire includes five scales to represent the opinions of respondents (1- Strongly Disagree, 2Disagree, 3- Average, 4- Agree, and 5- Strongly Agree). This research was conducted in several districts in Johor, Malaysia, which include Johor Bahru, Kota Tinggi, Pontian, Kulai Jaya, Muar, Batu Pahat, Segamat and Kluang. The sample chosen is based on purposive sampling, which refers to Chua Yan Piaw's opinion on purposive sampling applies to the sampling method where a respondent is a group of individuals with specified characteristics (Chua, 2012). The research requires 100 respondents, 60 from agency staff, which was responsible for granting loans to micro-entrepreneurs and 40 from micro-entrepreneurs.

\section{Results:-}

Questionnaire Result:

In order to obtain more information, the data collected through the questionnaires were analyzed in several simple ways. More than half (56 percent) of respondents agree that assessments that prioritize annual sales income do not benefit entrepreneur value, as shown in Figure 1. While 27\% of respondents strongly believe that they are not in favor of their annual profits. The rest of the respondents (17\%) felt that annual sales benefits could impact or not affect the assessment of the application of loans. Therefore approximately 83 percent of respondents do not really approve when a loan or assist ratings are based solely on annual sales profit.

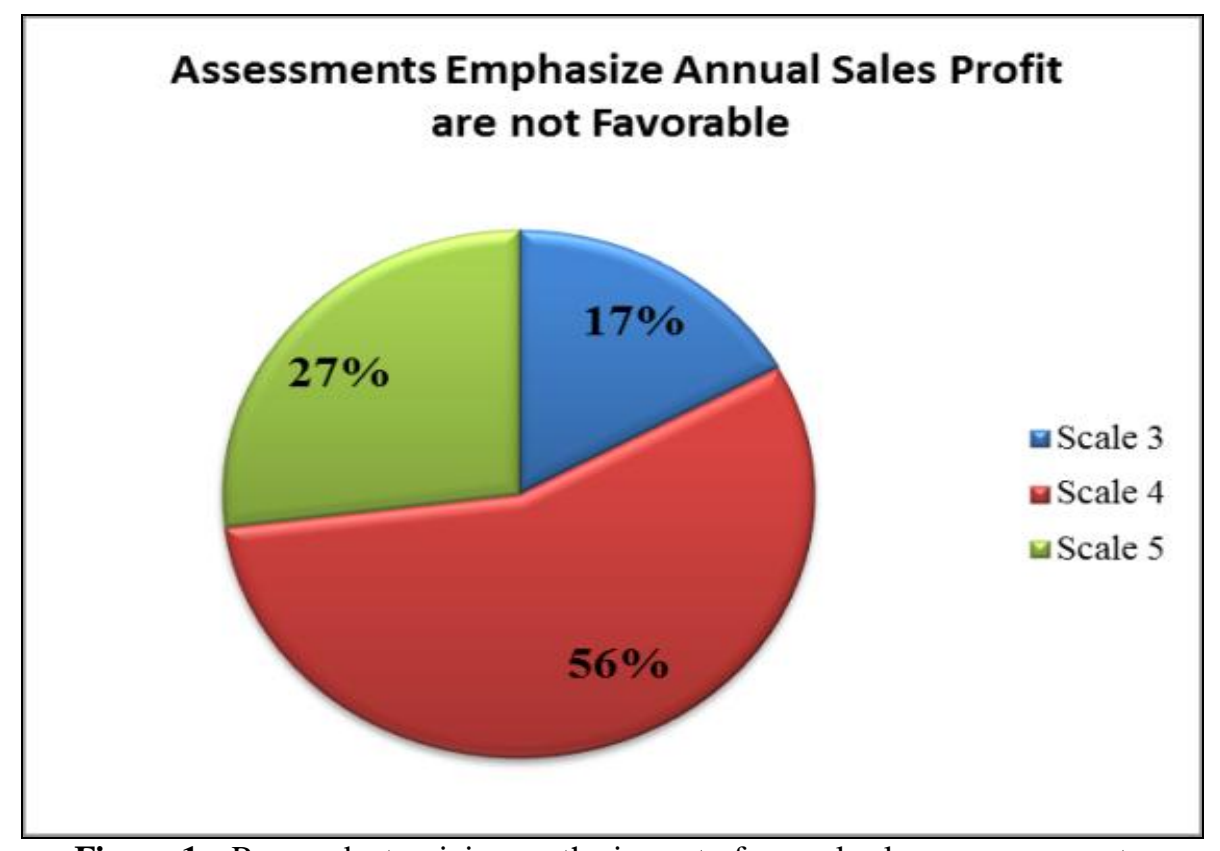

Figure 1:- Respondent opinion on the impact of annual sales on assessments. 


\section{Personality Traits Influence Entrepreneurship.}

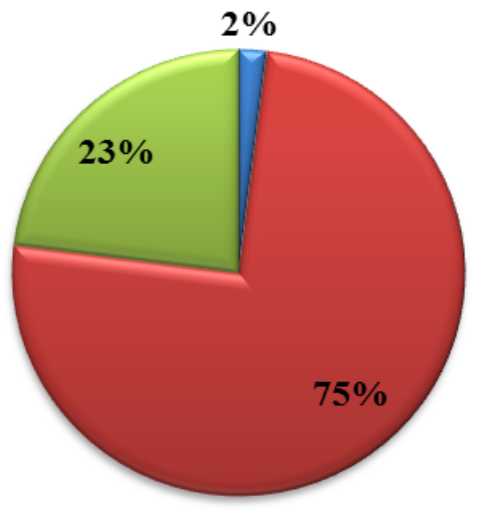

$\square$ Scale 3

arcale 4

$\square$ Scale 5

Figure 2:- Respondent opinions on personality traits influence the entrepreneurship.

Another analysis showed $88 \%$ of respondents agree that personality traits can influence an entrepreneur's success. $75 \%$ of respondents chose to respond that they agree on the question, and another $23 \%$ indicated that they totally agreed that traits play a vital role in their business development (Figure 2). Only $2 \%$ are unsure if personality traits play a significant role in the success of their business. A general conclusion can be made from the data obtained that most respondents agree on the importance of personality as an influencer in entrepreneurship. Their opinions are consistent with past findings (De Pillis \& Reardon, 2007; Nga \& Shamuganathan, 2010; Nishantha, 2009; Wang, Chang, Yao, \& Liang, 2016; Zainol \& Ayadurai, 2011).

\section{SmartPLS3 Result:}

Data analytics was applied using structural equation modeling (SEM). The structural design of the structural model shown in Figure 3 has been validated with SmartPLS 3. Wold (1980) advised that PLS is not suitable for confirmatory research but should be used for prediction and potential causality exploration. This software was used in this research, as this study was exploratory. Figure 4 demonstrates that the outcome has three main characteristics, which are persistence, determination, and opportunity oriented. Figure 4(a) shows the original result without modification or change. However, in order to make the findings of this research valid, the Composite Realibility (CR) must reach 0.708 , the 0.6 to 0.7 value already appropriate for exploratory research (Hair Jr, Hult, Ringle, \& Sarstedt, 2016). Several variables (rectangle form) with a value of less than 0.6 were removed to obtain values greater than 0.6, as shown in Figure 4(b). For example, the variable PERST CA1 and PERST CA2 were deleted by the fact that they are not reliable in a latent variable of persistence.

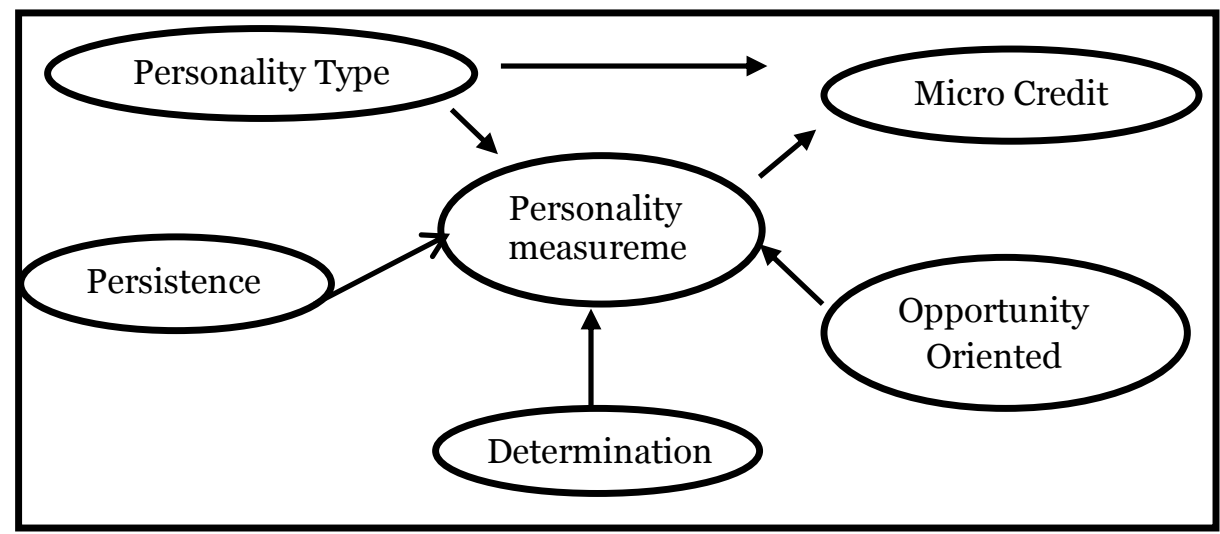

Figure 3:- Structural Model. 


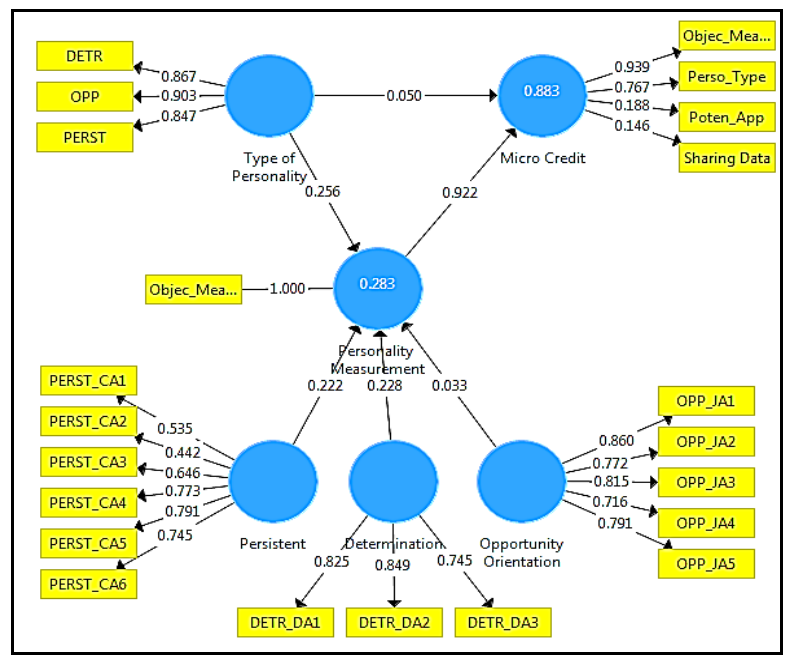

(a)

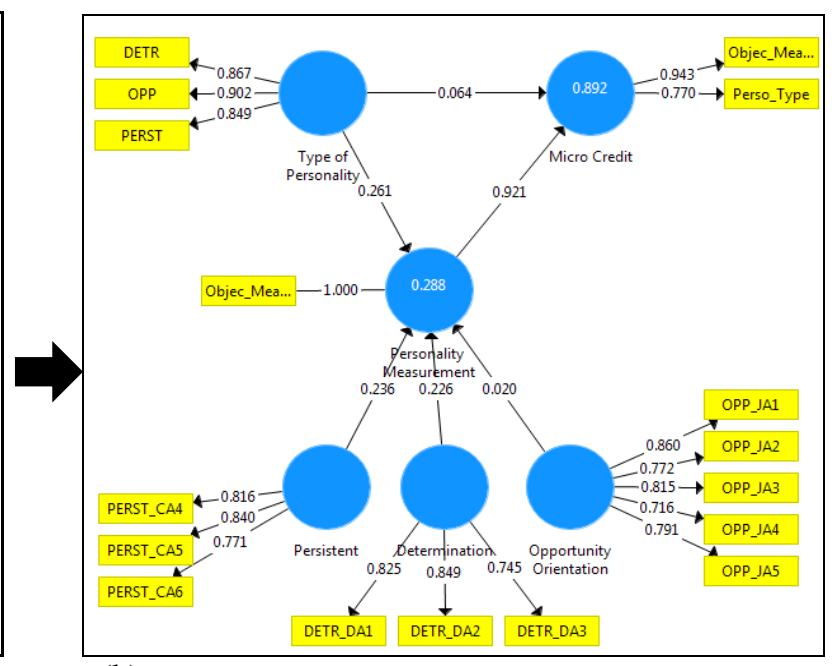

(b)

Figure 4:- Path model in SmartPLS3.

\section{Discussion:-}

Composite reliability, convergent, and discriminating validity, as in Figure 4, must be examined in order to validate the result. These tests were done to show prediction, direction relationship, the key factor, relevant relation, and statistical error. Three tests were done, such as:

1. Composite reliability (CR)

2. Factor loading, and Average Variance Extracted (AVE)

3. Discriminant validity, which consist of Heterotrait-Monotrait (HTMT)

$\mathrm{CR}$ is used to assess internal consistency reliability. The 'Cronbach alpha' is commonly used in social science research to measure inner accuracy. However, in measuring PLS-SEM, it appears to be conservative. Cronbach alpha is used to test the reliability of the item by calculating the correlation intensity in each one-dimensional structure between items in questionnaires. Composite reliability was proposed in previous literature as a substitute (Bagozzi \& Yi, 1988; Hair, Sarstedt, Ringle, \& Mena, 2012). Hair et al. (2012) reported that if values greater than 0.708 are seen to represent high internal consistency levels, all three variables have reflective latent variables. The following equation can be used to measure this $C R$ value:

$=\frac{\left(\sum \lambda_{i}\right)^{2} \operatorname{var} F}{\left(\sum \lambda_{i}\right)^{2} \operatorname{var} F+\sum \Theta_{i i}}$,

\section{CR}

where $\lambda_{\mathrm{i}}, \mathrm{F}$, and,$\Theta_{\mathrm{ii}}$ are the factor loading, factor variance, and unique/error variance respectively (Chin, 2010). If the value is below 0.60 , the result indicates a lack of internal consistency. The values from 0.60 to 0.70 are sufficient for exploratory research. The required value is between 0.70 and 0.90 to achieve adequate reliability (Nunnally $\&$ Bernstein, 1994). Unfortunately, all indicators measuring the same phenomenon indicate if the values exceed 0.90 (multicollinearity form of overlapping). In this research, composite reliability values exhibit more than 0.8 suggesting good reliability of the result as shown in Table 1.

Table 1:- Result Composite reliability and Validity.

\begin{tabular}{|l|l|l|l|l|}
\hline & Cronbach's alpha & rho_A & Composite Reliability (CR) & $\begin{array}{l}\text { Average } \\
\text { Extracted (AVE) }\end{array}$ \\
\hline Determination & 0.738 & 0.762 & 0.849 & 0.652 \\
\hline Micro Credit & 0.678 & 0.879 & 0.850 & 0.741 \\
\hline Opportunity Oriented & 0.856 & 0.898 & 0.894 & 0.627 \\
\hline Persistence & 0.762 & 0.787 & 0.845 & 0.580 \\
\hline Personality Measurement & 1.000 & 1.000 & 1.000 & 1.000 \\
\hline Personality Type & 0.845 & 0.869 & 0.906 & 0.762 \\
\hline
\end{tabular}


The convergent validity refers to the degree of correlation between two measures. Convergent validity is usually the reliability of the predictor (outer loading) and the average variance extracted (AVE). The reliability of the indicator should be 0.70 or higher to boost CR. The value should be 0.5 or higher for the AVE (Bagozzi \& Yi, 1988). The AVE value can be calculated formula follows:

$$
A V E=\frac{\left(\sum \lambda_{i}{ }^{2}\right) \operatorname{var} F}{\left(\sum \lambda_{i}{ }^{2}\right) \operatorname{var} F+\sum \Theta_{i i}}
$$

where ${ }^{\lambda_{\mathrm{i}}}, \mathrm{F}$, and, $\Theta_{\mathrm{ii}}$ are the factor loading, factor variance, and unique/error variance respectively (Chin, 2010). AVE is the portion of the information defined by each structure (unrelated variables) (Ringle, Da Silva, \& Bido, 2015). The model converges with a good result if AVE values surpass 0.5 (Fornell \& Larcker, 1981) (Table 1). For this research, the outer loading shows values above 0.7 describing the relation between the measurements used (Table 2). It means that all personalities are linked and affect entrepreneurship. In general, this CR value can be accepted and supports the relationship between connected constructs. The Discriminant validity was analyzed in order to determine how different a construct is from the other. There are three categories that must be taken into account which were Heterotrait-Monotrait (HTMT), Cross loading (item - construct) and Fornell-Larcker Criterion.

Table 2:- Indicator Reliability (Outer Loading) Values.

\begin{tabular}{|l|l|l|l|l|l|l|}
\hline & Determination & Micro Credit & $\begin{array}{l}\text { Opportunity } \\
\text { Oriented }\end{array}$ & Persistence & $\begin{array}{l}\text { Personality } \\
\text { Measurement }\end{array}$ & Personality Type \\
\hline DETR & & & & & & 0.867 \\
\hline DETR_DA1 & 0.825 & & & & & \\
\hline DETR_DA2 & 0.849 & & & & & \\
\hline DETR_DA3 & 0.745 & & & & & 0.902 \\
\hline OPP & & & 0.860 & & & \\
\hline OPP_JA1 & & & 0.772 & & & \\
\hline OPP JA2 & & & 0.815 & & & \\
\hline OPP JA3 & & & 0.716 & & & \\
\hline OPP JA4 & & & 0.791 & & & \\
\hline OPP JA5 & & & & & & \\
\hline OBJEC_MEAS & & 0.943 & & & & \\
\hline OBJEC_MEAS & & & & & & \\
\hline PERST & & & & & & \\
\hline PERST_CA4 & & & & & & \\
\hline PERST_CA5 & & & & & & \\
\hline PERST_CA6 & & & & & & \\
\hline Perso_Typ & & & & & & \\
\hline
\end{tabular}

However, previous studies suggested that HTMT is more acceptable than Cross loading and Fornell-Larcker because these two are not accurate in their perception that specific investigations lack diversity invalidity (Henseler, Ringle, \& Sarstedt, 2015; Rönkkö \& Evermann, 2013). The HTMT value was 1.056 for personality evaluation and 0.885 for persistence, which was higher than 0.8 , which is the most conservative critical HTMT value. This indicated that the HTMT criterion distinguishes problems of collinearity between the latent constructs (Table 3). The construct of Determination-Persistent and Micro Credit-Personality Measurement was problematic as some construct would calculate the same thing. This was implied from the perspectives of the respondents, which include the contrasting elements of the structures involved.

Table 3:- Heterotrait-Monotrait (HTMT) Values

\begin{tabular}{|l|l|l|l|l|l|l|}
\hline & Determination & Micro Credit & $\begin{array}{l}\text { Opportunity } \\
\text { Oriented }\end{array}$ & Persistence & $\begin{array}{l}\text { Personality } \\
\text { Measurement }\end{array}$ & $\begin{array}{l}\text { Personality } \\
\text { Type }\end{array}$ \\
\hline Determination & & & & & & \\
\hline Micro Credit & 0.538 & & & & & \\
\hline $\begin{array}{l}\text { Opportunity } \\
\text { Oriented }\end{array}$ & 0.341 & 0.394 & & & \\
\hline
\end{tabular}




\begin{tabular}{|l|l|l|l|l|l|l|}
\hline Persistence & 0.873 & 0.568 & 0.362 & & & \\
\hline $\begin{array}{l}\text { Personality } \\
\text { Measurement }\end{array}$ & 0.460 & 1.056 & 0.270 & 0.462 & & \\
\hline Personality Type & 0.159 & 0.488 & 0.512 & 0.242 & 0.360 & \\
\hline
\end{tabular}

Table 4:- Collinearity Statistic Values.

\begin{tabular}{|l|l|l|l|}
\hline & VIF & & VIF \\
\hline DETR & 2.074 & OPP_JA5 & 2.114 \\
\hline DETR_DA1 & 1.410 & OBJEC_MEASUR & 1.000 \\
\hline DETR_DA2 & 1.564 & OBJEC_MEASUR & 1.357 \\
\hline DETR_DA3 & 1.450 & PERST & 1.939 \\
\hline OPP & 2.079 & PERST_CA4 & 1.797 \\
\hline OPP_JA1 & 2.466 & PERST_CA5 & 1.757 \\
\hline OPP_JA2 & PERST_CA6 & 1.253 \\
\hline OPP_JA3 & Perso_Type & 1.357 \\
\hline OPP_JA4 & 1.019 & & \\
\hline
\end{tabular}

In order to ensure each element is different from each other, the test of the Variance Inflation Factor (VIF) was analyzed (Table 4). If any items are correlated, then there is multicollinearity. VIF is checked to ensure that there is no collinearity. The collinearity is high when $\mathrm{VIF}>5$ or $\mathrm{VIF}<0.2$. The results indicated that the statistical values of Collinearity are above 0.2 but not above 5 . The analysis, therefore, indicated no collinearity. R Square (R2) is evaluated to assess model accuracy. This test explained the amount of variation in the Dependent Variance (DV), as shown by all Independent Variation (IV) associated with this Variance. R2 $=0.2$ is high in user behaviour, while 0.75 is high in marketing; 0.5 is simple; 0.25 is low. The findings of this research show that the calculated Micro Credit is (0.892) and Personality Measurement is (0.288). Therefore, Micro Credit is high, and Personality Measurement value is considered moderate (Table 5).

Table 5:- R Square Values.

\begin{tabular}{|l|l|l|}
\hline & R Square & R Square Adjusted \\
\hline Micro Credit & 0.892 & 0.890 \\
\hline Personality Measurement & 0.288 & 0.258 \\
\hline
\end{tabular}

Table 6:- f Square Values.

\begin{tabular}{|l|l|l|l|l|l|l|}
\hline & Determination & Micro Credit & $\begin{array}{l}\text { Opportunity } \\
\text { Oriented }\end{array}$ & Persistence & $\begin{array}{l}\text { Personality } \\
\text { Measurement }\end{array}$ & Personality Type \\
\hline Determination & & & & & 0.042 & \\
\hline Micro Credit & & & & & & \\
\hline $\begin{array}{l}\text { Opportunity } \\
\text { Oriented }\end{array}$ & & & & & 0.001 & \\
\hline Persistence & & & & & 0.036 & \\
\hline $\begin{array}{l}\text { Personality } \\
\text { Measurement }\end{array}$ & & 6.990 & & & & \\
\hline $\begin{array}{l}\text { Personality } \\
\text { Type }\end{array}$ & 0.034 & & & 0.078 & \\
\hline
\end{tabular}

F square (f2) is used to measure the effect size f2, or otherwise to check the actual effect, which is indicated in DV in IV. For example, under the Micro Credit column, 6.990 is the predictive value of Micro Credit against personality measurements. The value of 6.990 indicates that personality influence has a higher effect in producing R2 for Micro Credit (Table 6).

\section{Conclusion:-}

Unlike conventional non-spatial ways, this paper presents a different way of measuring human personality and behaviors "unmeasurable". By quantifying and comparing with the spatial elements, human personality traits, and behaviors which are also called subjective, can be objectively measured with technology, instruments, and method 
available. The uses of the Structural Equation Modeling (SEM) for personality traits and behaviors can be evaluated in various types of methods to measure both personality traits and behaviors. These data help related organizations to analyses the behaviors of entrepreneurs to make better investments for potential entrepreneurs. By using this spatial measurement to identify potential entrepreneurs, loans, and aids can be optimized for business development. In turn, this promotes business growth and can generate more employment opportunities as well as reduce poverty.

\section{References:-}

1. Ahmad, M., \& Kadir, S. A. (2013). Characteristics of entrepreneurs and the practice of Islamic Values in influencing the success of small medium enterprises in Kelantan and Selangor. Journal of Social and Development Sciences, 4(5), 229-235.

2. Alessandretti, L., Lehmann, S., \& Baronchelli, A. (2018). Understanding the interplay between social and spatial behaviour. EPJ Data Science, 7(1), 36.

3. Bagozzi, R. P., \& Yi, Y. (1988). On the evaluation of structural equation models. Journal of the academy of marketing science, 16(1), 74-94.

4. Baumeister, R. F., Vohs, K. D., \& Funder, D. C. (2007). Psychology as the Science of Self-Reports and Finger Movements: Whatever Happened to Actual Behavior? Perspectives on Psychological Science, 2(4), 396-403. doi:10.1111/j.1745-6916.2007.00051.x

5. Chin, W. W. (2010). How to write up and report PLS analyses. In Handbook of partial least squares (pp. 655690): Springer.

6. Chua, Y. P. (2012). Mastering research methods: Mcgraw-Hill Education.

7. Conway, J. M., Jako, R. A., \& Goodman, D. F. (1995). A meta-analysis of interrater and internal consistency reliability of selection interviews. Journal of Applied Psychology, 80(5), 565.

8. de-Juan-Ripoll, C., Soler-Domínguez, J. L., Guixeres, J., Contero, M., Álvarez Gutiérrez, N., \& Alcañiz, M. (2018). Virtual Reality as a New Approach for Risk Taking Assessment. Frontiers in Psychology, 9(2532). doi:10.3389/fpsyg.2018.02532

9. De Pillis, E., \& Reardon, K. K. (2007). The influence of personality traits and persuasive messages on entrepreneurial intention: A cross-cultural comparison. Career development international, 12(4), 382-396.

10. Dipboye, R. L. (1994). Structured and unstructured selection interviews: Beyond the job-fit model. Research in personnel and human resources management, 12, 79-123.

11. Esri. (2003). Geographic Inquiry: Thinking Geographically. Retrieved from www.esri.com

12. Fornell, C., \& Larcker, D. F. (1981). Structural equation models with unobservable variables and measurement error: Algebra and statistics. In: SAGE Publications Sage CA: Los Angeles, CA.

13. Hachana, R., Berraies, S., \& Ftiti, Z. (2018). Identifying personality traits associated with entrepreneurial success: does gender matter? Journal of Innovation Economics Management(3), 169-193.

14. Hair, J. F., Sarstedt, M., Ringle, C. M., \& Mena, J. A. (2012). An assessment of the use of partial least squares structural equation modeling in marketing research. Journal of the academy of marketing science, 40(3), 414433.

15. Hair Jr, J. F., Hult, G. T. M., Ringle, C., \& Sarstedt, M. (2016). A primer on partial least squares structural equation modeling (PLS-SEM): Sage publications.

16. Hammersley, M. (2013). The myth of research-based policy and practice: Sage.

17. Henseler, J., Ringle, C. M., \& Sarstedt, M. (2015). A new criterion for assessing discriminant validity in variance-based structural equation modeling. Journal of the academy of marketing science, 43(1), 115-135.

18. Hogan, J., Barrett, P., \& Hogan, R. (2007). Personality measurement, faking, and employment selection. Journal of Applied Psychology, 92(5), 1270.

19. Kwan, M.-P. (2000). Analysis of human spatial behavior in a GIS environment: Recent developments and future prospects. Journal of Geographical Systems, 2(1), 85-90. doi:10.1007/s101090050034

20. Longley, P. A., Goodchild, M. F., J., M. D., \& Rhind, D. W. (2001). Geographic Information Systems and Science. : John Wiley \& Sons Ltd. Reproduced

21. Nga, J. K. H., \& Shamuganathan, G. (2010). The influence of personality traits and demographic factors on social entrepreneurship start up intentions. Journal of Business Ethics, 95(2), 259-282.

22. Nishantha, B. (2009). Influence of personality traits and socio-demographic background of undergraduate students on motivation for entrepreneurial career: the case of Sri Lanka.

23. Nunnally, J., \& Bernstein, I. (1994). Psychometric theory, . New York McGraw-Hill.

24. Nwachukwu, A. (2012). The role of entrepreneurship in economic development: The Nigerian perspective. European Journal of Business and Management, 4(8), 96. 
25. Phellas, C. N., Bloch, A., \& Seale, C. (2011). Structured methods: interviews, questionnaires and observation. Researching society and culture, 3 .

26. Podsakoff, P. M., MacKenzie, S. B., Lee, J.-Y., \& Podsakoff, N. P. (2003). Common method biases in behavioral research: A critical review of the literature and recommended remedies. Journal of Applied Psychology, 88(5), 879.

27. Ringle, C., Da Silva, D., \& Bido, D. (2015). Structural equation modeling with the SmartPLS. Bido, D., da Silva, D., \& Ringle, C.(2014). Structural Equation Modeling with the Smartpls. Brazilian Journal Of Marketing, 13(2).

28. Rönkkö, M., \& Evermann, J. (2013). A critical examination of common beliefs about partial least squares path modeling. Organizational Research Methods, 16(3), 425-448.

29. Uher, J. (2015). Conceiving "personality": psychologist's challenges and basic fundamentals of the Transdisciplinary Philosophy-of-Science Paradigm for Research on Individuals. Integrative Psychological and Behavioral Science, 49(3), 398-458.

30. Wang, J.-H., Chang, C.-C., Yao, S.-N., \& Liang, C. (2016). The contribution of self-efficacy to the relationship between personality traits and entrepreneurial intention. Higher Education, 72(2), 209-224. doi:10.1007/s10734015-9946-y

31. Wold, H. (1980). Model construction and evaluation when theoretical knowledge is scarce: Theory and application of partial least squares. In Evaluation of econometric models (pp. 47-74): Elsevier.

32. Youyou, W., Kosinski, M., \& Stillwell, D. (2015). Computer-based personality judgments are more accurate than those made by humans. Proceedings of the National Academy of Sciences, 112(4), 1036-1040. doi:10.1073/pnas.1418680112

33. Zainol, F. A., \& Ayadurai, S. (2011). Entrepreneurial orientation and firm performance: the role of personality traits in Malay family firms in Malaysia. International Journal of Business and Social Science, 2(1). 